\title{
POSTUPAK U SPOROVIMA MALE VRIJEDNOSTI U SVJETLU ODREDABA NOVELE ZPP 2019.
}

Prof. dr. sc. Jozo Čizmić*

\author{
UDK: $347.919 .3(497.5)$ \\ https://doi.org/10.30925/zpfsr.41.1.11 \\ Ur.: 10. siječnja 2020. \\ Pr.: 10. ožujka 2020. \\ Pregledni rad
}

\begin{abstract}
Sažetak
Odredbe Zakona o izmjenama i dopunama Zakona o parničnom postupku (Narodne novine, broj 70/2019) počele su se primjenjivati 1. rujna 2019. i njima su unesene bitne promjene u postupku u sporovima male vrijednosti. Svrha je reforme odredaba kojima se uređuje postupak u sporovima male vrijednosti omogućavanje bržega, učinkovitijeg i jednostavnijega rješavanja predmeta, koji svojim brojem opterećuju sudove, a čija visina nije takva da bi zahtijevala veće angažiranje stranaka i suda. Tako je zakonodavac, radi veće procesne discipline stranaka, reformirao odredbe o dužnosti iznošenja činjenica i predlaganja dokaza; o (presumiranom) povlačenju tužbe; razlozima za žalbu i suspenzivnom učinku žalbe te je ukinuo obvezu objavljivanja presude odmah nakon zaključenja glavne rasprave $i$ mogućnost izjavljivanja izvanredne revizije. Kako je normativno uređenje postupka u sporovima male vrijednosti gotovo redovito bilo određeni test za kasniju promjenu uređenja redovnog postupka, autor vjeruje da će ova rješenja, nakon njihove primjene u praksi, kao i stajališta sudske prakse i procesno-pravne teorije, ukazati na opravdanost njihova uvođenja u postupak u sporovima male vrijednosti te da će biti putokaz zakonodavcu da ih provede i $u$ odredbe ZPP-a kojima se uređuje, tzv. opći parnični postupak radi provođenjem brzog, učinkovitog i racionalnoga parničnog postupka.
\end{abstract}

Ključne riječi: parnični postupak; spor male vrijednosti.

\section{1. $U V O D$}

Katkada opća procesna pravila nisu prikladni instrument za pružanje pravne zaštite u sporovima koji se zbog svojih posebnosti bitno razlikuju od standardnih. Zato se u predmetima u kojima primjena općih procesnih pravila ne bi potpuno udovoljila svim oblicima pružanja pravne zaštite, primjenjuju pravila predviđena za posebne postupke. U tim se predmetima odredbe općih pravila primjenjuju samo ako nisu derogirane odredbama posebnih postupaka, po pravilu: lex specialis derogat legi generali, ${ }^{1}$ kao

* Dr. sc. Jozo Čizmić, redoviti profesor u trajnom zvanju, Pravni fakultet Sveučilišta u Splitu; jcizmic@pravst.hr.

1 Usp. Branko Čalija, Građansko procesno pravo (Sarajevo: Pravni fakultet, 2017.), 632. 
supsidijarni izvor prava. Opći je postupak univerzalan jer sadrži sva pravila za postupanje u parničnom postupku, dok je posebni postupak singularan i sadrži samo ona pravila koja odstupaju od općeg postupka. Više je razloga za propisivanje posebnih postupaka. Oni su ili u društvenom značenju spora koji se uređuje posebnim postupkom, ili u posebnom materijalno-pravnom odnosu koji je predmet spora, ili potrebni da se sudska odluka donese hitno i po jednostavnijoj proceduri. Potreba za posebnim pravilima uvjetovana je katkada zahtjevom za hitnim pružanjem zaštite; u drugim, izgledima za racionalnim reduciranjem procesnih stadija; u trećim, ograničeni zadatci zaštite uvjetuju reduciranje raspravne teme; ponegdje se zbog općedruštvenog značenja sporova predviđa proširenje oficijelnih i inkvizicijskih ovlaštenja suda; u određenim sporovima specifična priroda subjekata uvjetuje posebni tretman pri rješavanju njihovih parnica; katkad propisivanje posebnih postupaka. ${ }^{2} \mathrm{U}$ tom smislu, Zakon o parničnom postupku Republike Hrvatske, Službeni list, br. 4/77., 36/77., 6/80., 36/80., 43/82., 69/82., 58/84., 74/87., 57/89., 20/90., 27/90., Narodne novine, br. 35/91., 53/91., 91/92., 112/99., 88/01. čl. 50. Zakon o arbitraži, 117/03., 84/08., 123/08., 57/11., 148/1.1, 25/13., 43/13. Rješenje USRH, 89/14 - OUSRH i 70/19 (dalje u tekstu: ZPP) sadrži i odredbe za posebni parnični postupak u sporovima male vrijednosti (glava 30.).

Pravila o postupku u sporovima male vrijednosti rezultat su određenoga kompromisa između radikalne primjene načela de minimis non curat praetor i težnje da se strankama osiguraju procesna jamstva za zakonitu zaštitu prava. ${ }^{3} \mathrm{U}$ sporovima male vrijednosti postupak je pojednostavljen, pojedine procesne radnje potpuno su reducirane dok se neke poduzimaju u skraćenom obliku, a sve zbog načela ekonomičnosti (v. čl. 10. ZPP), odnosno da bi se uskladili troškovi postupka s imovinskim zahtjevom koji se ostvaruje u ovim sporovima. Sporovi male vrijednosti po svojim se obilježjima od općeg parničnog postupka razlikuju u elementu ratione valoris, $\mathrm{tj}$. u vrijednosti predmeta spora. Načelno gledano, kod sporova male vrijednosti ne postoji neka osobitost predmeta koja bi uvjetovala njegovo izdvajanje u posebni postupak, ali priroda predmeta spora nije kriterij za razgraničenje tih postupaka. Spor male vrijednosti nema sebi svojstven predmet spora. Ovaj posebni postupak vrijedi u načelu za sve imovinsko-pravne stvari male vrijednosti. Dok je kod većine sporova razlog izdvajanja u zaseban postupak materijalno-pravne prirode, tj. rationae materiae, kod sporova male vrijednosti razlog izdvajanja u poseban postupak ogleda se ponajprije u (relativno) malom društvenom, odnosno ekonomskom značaju. ${ }^{4}$ Svrha je postupka u sporovima male vrijednosti da, s obzirom na malu vrijednost predmeta spora, olakša i znatno ubrza sudski postupak u rješavanju takvih sporova, štiteći ujedno prava stranaka jednako kao u redovnom parničnom postupku. ${ }^{5}$

2 Tako Siniša Triva, Velimir Belajec i Mihajlo Dika, Građansko parnično procesno pravo (Zagreb: Narodne novine, 1986.), 625, vidi i Jozo Čizmić, „Postupak u sporovima male vrijednosti “, Hrvatska pravna revija 2, br. 1 (2002.): 113.

3 Triva, Belajec i Dika, Građansko parnično procesno pravo, 670.

4 Marija Salma, „Postupak u sporovima male vrednosti“, Zbornik radova Pravnog fakulteta u Novom Sadu br. 2 (2010.): 121.

5 Iva Benzon i Marija Vujeva, „Postupak u sporovima male vrijednosti - Analiza procesnih instituta u teoriji i praksi nakon Novele Zakona o parničnom postupku iz 2013.“, Pravnik 48, 1(98) (2015.): 23. 
Sporovi male vrijednosti zauzimali su važno mjesto u svakoj novijoj reformi hrvatskoga parničnog postupka (Novele 2003., 2008., 2011., 2013.) u kojima se postavljao zahtjev za provođenjem brzog, učinkovitog i racionalnog postupka, pa i u ovim sporovima koji, s obzirom na vrijednosni kriterij, nemaju ili ne bi trebali imati veliku važnost. Normativno uređenje takvih sporova gotovo je redovito bilo određeni test za kasniju promjenu uređenja redovnog postupka. Naime, nakon što bi se određena zakonska promjena u sustavu procesno-pravnoga uređenja sporova male vrijednosti pokazala dobrom, bila bi u značajnoj mjeri podloga za zakonske izmjene i uvođenje takvih rješenja u redovni postupak. Kako je broj takvih sporova pred našim sudovima još uvijek iznimno velik, razumljiva su nastojanja zakonodavca za čestim izmjenama procesnog zakona upravo, a sve kako bi se njihov broj smanjio. ${ }^{6}$ Tako su donesena i Okvirna mjerila za rad sudaca koja predviđaju da sudac na prvom stupnju godišnje riješi 400 predmeta u sporovima male vrijednosti. Ta bi brojka racionalno bila moguća kada bi ti sporovi male vrijednosti bili jednostavni predmeti (npr. u slučaju neplaćanja komunalnih usluga, telefona i sl.), no, s obzirom na visoko označenu vrijednost predmeta spora, u skupinu sporova male vrijednosti ulazi veliki broj složenijih predmeta. ${ }^{7}$ Zbog malog iznosa vrijednosti spora sud nije ovlašten odbaciti tužbu, već je dužan odlučiti o tužbenom zahtjevu. ${ }^{8}$

ZPP ne daje izrijekom definiciju spora male vrijednosti, nego samo propisuje kriterije za određivanje spora male vrijednosti pred redovnim sudovima (čl. 458.-460. ZPP), odnosno pred trgovačkim sudovima (čl. 502. ZPP).

Postupak u sporovima male vrijednosti (njem. Verfahren in den geringfuegigen Steritigkeiten; engl. small claims disputes) poseban je sumarni (bagatelni, malični) postupak koji se provodi u njima.

Sporovi male vrijednosti su sporovi u kojima se tužbeni zahtjev odnosi na potraživanje u novcu koje ne prelazi svotu od 10.000,00 kuna (čl. 458. st. 1. ZPP). Nužno je istaknuti da u parničnom postupku po tužbi kojom se potražuje glavnica i kamata, postupak će se provesti po odredbama o postupku u sporovima male vrijednosti ako se tužbeni zahtjev odnosi na glavno potraživanje koje ne prelazi iznos od 10.000,00 kuna, jer se pritom kamata i ostala sporedna potraživanja ne uzimaju u obzir (arg. čl. 35. ZPP). Kod objektivne kumulacije trebalo bi ocjenjivati vrijednost svakoga zahtjeva, a ne njihov zbroj. Ako bi o nekom od kumuliranih zahtjeva trebalo provesti redovni, a o drugim ovaj sumarni postupak, zahtjeve bi trebalo razdvojiti. Ali, ako zahtjevi potječu iz iste činjenične i pravne osnove, trebalo bi o svima suditi na temelju rezultata redovitog postupka. ${ }^{9}$

Prema odredbi čl. 458. st. 2. ZPP-a sporovima male vrijednosti smatraju se i sporovi u kojima se tužbeni zahtjev ne odnosi na potraživanje u novcu, ali je tužitelj u tužbi naveo da pristaje da umjesto udovoljenja određenom zahtjevu primi određeni

6 Zinka Bulka i Dražen Jakovina, Sporovi male vrijednosti (Zagreb: Pravosudna akademija, 2016.), 4.

7 Jelena Čuveljak, Sporovi male vrijednosti prema noveli Zakona o parničnom postupku 2019., IUS-INFO, pristup 27. 12. 2019., http://www.iusinfo.hr/Article/Content.aspx? SOPI $=$ CLN20V01D2019B1315\&Doc $=$ CLANCI HR.

8 Visoki trgovački sud Republike Hrvatske, Pž-4670/00 od 9. listopada 2001.

9 Triva, Belajec i Dika, Građansko parnično procesno pravo, 671. 
novčani iznos koji ne prelazi svotu od 10.000,00 kuna (vidi čl. 40. st. 1. ZPP). U sporovima male vrijednosti smatraju se i nenovčani sporovi u kojima je tužitelj istaknuo, tzv. facultas alternativu do iznosa od 10.000,00 kuna, odnosno sporovi u kojima se tužbeni zahtjev ne odnosi na potraživanje u novcu, a tužitelj je u tužbi naveo da pristaje da umjesto udovoljenja određenom zahtjevu primi novčani iznos koji ne prelazi svotu od 10.000,00 kuna. ${ }^{10} \mathrm{U}$ toj je situaciji bitno da je, pored nužnog kondemnatornoga zahtjeva, istaknuta, tzv. facultas alternativa u novčanom iznosu koji ne prelazi svotu od 10.000,00 kuna, odnosno u postupku pred trgovačkim sudovima od 50.000,00 kuna. ${ }^{11}$

Prema odredbi čl. 458. st. 3. ZPP-a sporovima male vrijednosti smatraju se i sporovi u kojima predmet tužbenog zahtjeva nije novčana svota, već predaja pokretne stvari čija vrijednost, koju je tužitelj u tužbi naveo, ne prelazi svotu iz st. 1. ovoga članka (vidi čl. 40. st. 2. ZPP). Naime, ako se tužbeni zahtjev odnosi na novčani iznos, označavanje visine tužbenoga zahtjeva ujedno je i označavanje vrijednosti predmeta spora. Ako se, pak, tužbeni zahtjev ne odnosi na novčani iznos, a tužitelj nije ni naveo novčani iznos koji je voljan primiti umjesto stvari, tužitelj je dužan u tužbi posebno označiti vrijednost predmeta spora. Ako to ne učini, sud će ga po pravilima o ispravljanju podnesaka pozvati da dopuni tužbu. Pritom naznačena vrijednost predmeta spora ne mora nužno odgovarati protuvrijednosti imovine koja je predmet spora. ${ }^{12}$ Tužitelj može vrijednost predmeta spora naznačiti i posredno, primjerice naznačavanjem visine pristojbe koju plaća na tužbu. ${ }^{13}$ Dakle, o dispoziciji bi tužitelja, zapravo, ovisilo hoće li sporu koji je pokrenuo pridati značenje spora male vrijednosti tako što će uz kondemnatorni zahtjev istaknuti procesno alternativno ovlaštenje. ${ }^{14}$

Postupak u sporovima male vrijednosti provodit će se i u povodu prigovora protiv platnog naloga ako vrijednost osporenog dijela platnog naloga ne prelazi svotu od 10.000,00 kuna (čl. 460. ZPP). Kad se tužbeni zahtjev odnosi na dospjelo glavno potraživanje u novcu koje ne prelazi svotu od 10.000,00 kuna, sud će izdati platni nalog protiv tuženika, iako tužbi nisu priložene vjerodostojne isprave, ali je u tužbi iznesena osnova i visina dugovanja i naznačeni su dokazi na temelju kojih se može utvrditi istinitost tužbenih navoda (čl. 447. st. 1. ZPP). U sporovima iz nadležnosti trgovačkih sudova ovaj platni nalog će se izdati kada se tužbeni zahtjev odnosi na dospjelu glavnu tražbinu u novcu koja ne prelazi svotu od 20.000,00 kuna (čl. 447. st. 2. ZPP). Odredbe ovoga članka, koje su u skladu s načelom ekonomičnosti parničnog postupka, odstupanje su od odredaba čl. 446. ZPP-a. Takvom formulacijom odredaba čl. 447. st. 1. ZPP-a, nastoji se maksimalno pojednostavniti i ubrzati postupak u sporovima male vrijednosti putem izdavanja platnog naloga i bez vjerodostojne isprave. Naime, pored platnih naloga koji se izdaju za potraživanja, čije postojanje tužitelj dokazuje kvalificiranim ispravama, tzv. dokumentirani platni nalozi, odredbama ovoga članka predviđen je platni nalog koji se izdaje za potraživanja, manje vrijednosti, o čijem postojanju tužitelj ne mora uz tužbu

10 Čizmić, Postupak u sporovima male vrijednosti, 114.

11 Bulka i Jakovina, Sporovi male vrijednosti, 6.

12 Vrhovni sud Republike Hrvatske, Rev-600/86. od 12. lipnja 1986.

13 Vrhovni sud Republike Hrvatske, Rev-656/78. od 21. ožujka 1979.

14 Mihajlo Dika, „Novelirani postupak u sporovima male vrijednosti“, Zbornik Pravnog fakulteta Sveučilišta u Rijeci 30, br. 1 (2009): 5. 
priložiti nikakva dokazna sredstva , tzv. nedokumentirani platni nalog..$^{15}$ Ako su u tužbi izneseni osnova i visina dugovanja, dostatno je, dakle, da tužitelj naznači dokaze na temelju kojih se može utvrditi istinitost tužbenih navoda, a to mogu biti sva dokazna sredstva predviđena u parničnom postupku. ${ }^{16}$ Ako su ispunjeni svi uvjeti iz st. 1. čl. 447. ZPP-a, platni nalog može se izdati samo protiv glavnoga dužnika, a ne, primjerice, protiv jamca i sporednih (regresnih) obveznika.

Nužno je istaknuti da su u praksi hrvatskih sudova sporovi male vrijednosti najčešći ako se, u povodu prigovora ovršenika protiv platnoga naloga sadržanog u javnobilježničkom rješenju o ovrsi, postupak nastavi pred sudom. U tim slučajevima, vrijednost predmeta spora uobičajeno iznosi svega nekoliko tisuća kuna, a predmet takvih parničnih postupaka najčešće su neplaćena potraživanja s osnove režija (struja, voda, plin), telekomunikacijskih usluga i sl. ${ }^{17}$

Prema odredbama ZPP-a ne smatraju se sporovima male vrijednosti sporovi o nekretninama, sporovi iz radnih odnosa koje je pokrenuo radnik protiv odluke o prestanku ugovora o radu i sporovi zbog smetanja posjeda (čl. 459. ZPP). S obzirom na značenje i prirodu tih sporova, posebna pravila o postupku u sporovima male vrijednosti ne primjenjuju se u navedenim sporovima. Sporovi o nekretninama, iz radnih odnosa i zbog smetanja posjeda po objektivnom su kriteriju isključeni od primjene posebnih odredaba za sporove male vrijednosti. ${ }^{18}$ Bit ovih negativnih kriterija za određivanje sporova male vrijednosti svodi se na propisivanje vrsta sporova koji se nikada ne smatraju sporovima male vrijednosti bez obzira na vrijednost predmeta spora i bez obzira na to što bi primjenom nekog od pozitivnih kriterija to mogli biti. Zakonodavac je propisivanjem takvih kriterija očito želio naglasiti važnost imovinskih prava o kojima se u njima odlučuje. ${ }^{19}$

Imovinski sporovi po tužbama za utvrđenje ne smatraju se sporovima male vrijednosti, bez obzira na vrijednost predmeta spora koja je navedena u tužbi. Međutim, za razliku od sporova o nekretninama koji se odnose na sporove o stvarnim pravima na nekretninama i o zahtjevu za predaju nekretnina u posjed, sporovi kojima se traži isplata cijene za nekretninu, naknada za korištenje nekretnine ili druga novčana potraživanja u svezi s nekretninom, smatraju se sporovima male vrijednosti ako potraživanje ne prelazi iznos od 10.000,00 kuna. ${ }^{20}$

Iako se sporovi iz radnih odnosa koje je pokrenuo radnik protiv odluke o prestanku ugovora o radu ne smatraju sporovima male vrijednosti, sporovi radi isplate plaće i drugih novčanih tražbina na temelju ugovora o radu mogli bi, a contrario,

15 Računi priloženi uz prijedlog za ovrhu vjerodostojna su isprava na temelju koje javni bilježnik može donijeti rješenje o ovrsi. Čim je podnesen prigovor u kojemu tuženik kao ovršenik osporava osnovu i visinu, takve isprave više nisu dostatne za dokazivanje izvršenja usluge, jer je riječ o jednostrano izdanim ispravama. Visoki trgovački sud Republike Hrvatske, Pž 3559/2017-2 od 28. rujna 2018.

16 Čizmić, Postupak u sporovima male vrijednosti, 117.

17 Preporuke za efikasnije vođenje sporova male vrijednosti (Zagreb: Američka gospodarska komora u Hrvatskoj, 2017.), 4.

18 Vrhovni sud Republike Hrvatske, II Rev-73/92. od 25. studenog 1992.

19 Bulka i Jakovina, Sporovi male vrijednosti, 7.

20 Dragoljub Petrović et al., Komentar Zakona o parničnom postupku (Beograd: Privredna štampa, 1977.), 477. 
imati značenje spora male vrijednosti. ${ }^{21}$ Radni spor u kojem radnik potražuje novčani iznos manji od 10.000,00 kn smatra se sporom male vrijednosti. ${ }^{22}$

U sporovima radi uzdržavanja ne primjenjuju se odredbe posebnoga zakona kojim se uređuje parnični postupak, koje se odnose na postupak u sporovima male vrijednosti (čl. 423. Obiteljskog zakona, Narodne novine, br. 103/15., 98/19.).

Parnica radi proglašenja ovrhe nedopuštenom nije spor male vrijednosti neovisno o naznačenoj vrijednosti te neovisno o visini novčane tražbine zbog čijeg se ostvarivanja vodi ovrha, ni onda kada ovršna tražbina ne prelazi svotu od 10.000,00 kuna. ${ }^{23}$

\section{NADLEŽNOST I PRIMJENA OSTALIH ODREDBI ZPP-A}

Postupak u sporovima male vrijednosti provodi se pred nižim sudovima prvog stupnja, ako ZPP-om nije drukčije određeno (čl. 461. ZPP). Ova odredba o „nižim sudovima prvog stupnja“ vuče svoje podrijetlo iz vremena kada je stvarna nadležnost prema vrijednosnom kriteriju bila podijeljena između tadašnjih viših i nižih prvostupanjskih sudova određene vrste, npr. između općinskih i okružnih (danas županijskih) sudova te okružnih privrednih (danas trgovačkih) i viših privrednih (danas Visokog trgovačkog suda) sudova. Budući da u Republici Hrvatskoj stvarna nadležnost prvostupanjskih sudova nije raspodijeljena prema vrijednosnom kriteriju, za sporove male vrijednosti mogu biti stvarno nadležni samo općinski i trgovački sudovi kao prvostupanjski sudovi. ${ }^{24}$

Sporove male vrijednosti sudi sudac pojedinac (arg. čl. 41. ZPP-a). S obzirom na vrijednosno određenje sporova male vrijednosti u svim bi tim sporovima prvostupanjski postupak mogao voditi sudski savjetnik (arg. čl. 13. st. 3. ZPP).

Posebne su odredbe o postupku u sporovima male vrijednosti ius cogens za suca. Ako bi ipak sudac u sporovima male vrijednosti primijenio odredbe redovnog postupka kada je morao primijeniti odredbe posebnog postupka, to samo po sebi ne bi bila apsolutno bitna povreda odredaba parničnog postupka. Mogla bi biti relativno bitna povreda odredaba parničnog postupka iz čl. 354. st. 1. ZPP-a, ako bi propuštanjem provođenja spora male vrijednosti po tom posebnom postupku, dovelo do situacije da je to moglo ili je utjecalo na donošenje pravilne i zakonite odluke. Okolnost da je prvostupanjski sud propustio primijeniti pravila o postupku u sporovima male vrijednosti nije bitna povreda odredaba parničnog postupka. To iz razloga što provođenje prvostupanjskog postupka po odredbama ZPP-a o redovnom postupku pruža veće jamstvo strankama u ostvarivanju procesnih i materijalno-pravnih ovlaštenja od odredbi koje propisuju postupanje u sporovima male vrijednosti. ${ }^{25}$

To znači da će se (u pravilu) i u sporovima male vrijednosti primjenjivati opći instituti parničnoga prava te pravila o redovnom parničnom postupku, osim ako je

21 Dika, Novelirani postupak u sporovima male vrijednosti, 6.

22 Vrhovni sud Republike Hrvatske, Revr 1678/2016-2 od 25. siječnja 2017.

23 Županijski sud u Bjelovaru, Gž-2091/12-2 od 24. svibnja 2013.

24 Dika, Novelirani postupak u sporovima male vrijednosti, 7.

25 Vrhovni sud Republike Hrvatske, Rev-1276/91. od 9. listopada 1991. 
izrijekom predviđeno što drugo. Ipak, u određenim se slučajevima opća pravila ne primjenjuju izravno, nego tek odgovarajući zato što je to tako izrijekom propisano. ${ }^{26}$

U postupku u sporovima male vrijednosti sud se može, po službenoj dužnosti ili u povodu prijedloga stranke, oglasiti stvarno i mjesno nenadležnim najkasnije do upuštanja tuženika u raspravljanje o glavnoj stvari (čl. 461.b ZPP). Sud se može proglasiti mjesno nenadležnim po službenoj dužnosti samo ako postoji isključiva mjesna nadležnost nekoga drugog suda, i to najkasnije na pripremnom ročištu ili, ako ono nije održano, do upuštanja tuženika u raspravljanje o glavnoj stvari. ${ }^{27}$ Tužitelj može istaknuti prigovor mjesne nenadležnosti tek nakon pravomoćnosti rješenja kojim je javnobilježničko rješenje o ovrsi stavljeno izvan snage, ako je parnični postupak iniciran prijedlogom za ovrhu protiv kojeg je ovršenik podnio prigovor. ${ }^{28}$

Ako tužitelj preinači tužbeni zahtjev tako da vrijednost predmeta spora prelazi svotu od 10.000,00 kuna, postupak će se dovršiti prema odredbama ZPP-a o redovnom postupku. Ako tužitelj do zaključenja glavne rasprave koja se vodi prema odredbama ovoga zakona o redovnom postupku smanji tužbeni zahtjev tako da više ne prelazi svotu od 10.000,00 kuna, daljnji se postupak treba provesti prema odredbama ZPP-a o postupku u sporovima male vrijednosti (čl. 464. ZPP). U tim bi situacijama, prema stajalištu doktrine, trebalo deklaratornom odlukom zaključiti da su ispunjeni uvjeti za nastavak postupka po pravilima o drukčijoj proceduri. ${ }^{29}$ Kod kumulacije tužbenih zahtjeva valjalo bi primijeniti odredbu čl. 37. ZPP-a o utvrđivanju vrijednosti predmeta spora. ${ }^{30}$

Kao i u redovitom postupku, tužitelj pod istim uvjetima može preinačiti tužbu do zaključenja glavne rasprave i u postupku u sporovima male vrijednosti. Ali, ako tužitelj preinači tužbeni zahtjev tako da vrijednost predmeta spora prelazi svotu od $10.000,00$ kuna, čime bi zbog preinačenja spor izgubio značenje spora male vrijednosti, postupak se treba dovršiti prema odredbama ZPP-a o redovnom postupku. Procesne radnje koje su poduzete prije preinačenja po pravilima koja vrijede za sporove male vrijednosti, ostaju na snazi. Suprotno, ako tužitelj do zaključenja glavne rasprave koja se vodi prema odredbama ZPP-a o redovnom postupku smanji tužbeni zahtjev tako da više ne prelazi svotu od 10.000,00 kuna, daljnji postupak provest će se prema odredbama ZPP-a o postupku u sporovima male vrijednosti. ${ }^{31}$

Kod objektivne kumulacije tužbenih zahtjeva trebalo bi ocijeniti vrijednost svakog zahtjeva, a ne njihov zbroj. Ako bi prema jednim zahtjevima trebalo provesti redoviti postupak, a prema drugim postupak koji se provodi u sporovima male vrijednosti, zahtjeve bi trebalo razdvojiti. Ako svi zahtjevi proizlaze iz iste činjenične i pravne osnove, o svim bi zahtjevima trebalo suditi prema pravilima redovitog postupka. $^{32}$

26 Dika, Novelirani postupak u sporovima male vrijednosti, 3.

27 Vrhovni sud Republike Hrvatske, Gr1 571/14-2 od 22. siječnja 2015.

28 Županijski sud u Varaždinu, Gž 2345/2017-2 od 22. prosinca 2017.

29 Dika, Novelirani postupak u sporovima male vrijednosti, 12.

30 Bulka i Jakovina, Sporovi male vrijednosti, 7.

31 Viši privredni sud SR Bosne i Hercegovine, Pž-1608/76.

32 Mladen Pavlović, „Osobitosti postupka u sporovima male vrijednosti, Pravo i porezi 1, br. 1 (2001.): 39 . 
Posebne odredbe o postupku u sporovima male vrijednosti treba primjenjivati uvijek kad tužbeni zahtjev pred prvostupanjskim sudom padne na iznos koji ne prelazi svotu od 10.000,00 kuna, bez obzira na razloge zbog kojih je došlo do sniženja vrijednosti spora. To znači kada u povodu drugostupanjske odluke prvostupanjski sud treba u ponovnom postupku odlučiti o preostalom spornom tužbenom zahtjevu, koji nakon donošenja odluke drugostupanjskog suda više ne prelazi svotu od 10.000,00 kuna. ${ }^{33}$

Ako u glavi 30. ZPP-a ne postoje posebne odredbe, u postupku u sporovima male vrijednosti primjenjivat će se ostale odredbe ZPP-a (čl. 457. ZPP).

Odstupanja od općega postupka ovdje su utemeljena na stajalištu da u sporovima čija vrijednost nije velika ne treba primjenjivati one odredbe koje parnicu čine složenijom i produžavaju njezino trajanje. Time se, istina, umanjuju jamstva za točnost presude, ali se postiže ekspeditivnost sudovanja u ogromnom broju sporova relativno manje važnosti. ${ }^{34}$ Međutim, i u sporu male vrijednosti sud je dužan potpuno $\mathrm{i}$ istinito utvrditi sporne činjenice o kojima ovisi osnovanost tužbenog zahtjeva. ${ }^{35}$

Treba uočiti da se ovdje nije riječ o „odgovarajućoj primjeni“ tih ostalih odredaba ZPP-a, nego o njihovoj izravnoj primjeni. ${ }^{36}$ Odredbe ZPP-a iz glave 32. o postupku pred trgovačkim sudovima ne isključuju odredbe tog zakona o postupku u sporovima male vrijednosti. ${ }^{37}$

\section{ODGOVOR NATUŽBU}

Člankom 93. Zakona o izmjenama i dopunama Zakona o parničnom postupku, Narodne novine, broj 70/2019 (dalje u tekstu: Novela) u cijelosti je izmijenjen čl. 461.a. Zakonodavac je ovim člankom želio propisati veću procesnu disciplinu stranaka u postupku u sporovima male vrijednosti. ${ }^{38}$ Nužno je istaknuti da su prva dva stavka ostala neizmijenjena. Drugim riječima i dalje je propisano da se u postupku u sporovima male vrijednosti tužba uvijek dostavlja tuženiku na odgovor te da su stranke dužne najkasnije u tužbi, odnosno odgovoru na tužbu iznijeti sve činjenice na kojima temelje svoje zahtjeve i predložiti dokaze potrebne za utvrđivanje iznesenih činjenica (čl. 461.a st. 1. i 2. ZPP). Propisivanjem izričite obveze sudu da uvijek dostavi tuženiku tužbu na odgovor, sud više ne može izravno zakazati prvo ročište bez da je tuženika pozvao da podnese odgovor na tužbu. Uvođenjem obveze dostave tužbe na odgovor u svim slučajevima ujedno je omogućeno ograničenje iznošenja novina na trenutak podnošenja tužbe, odnosno odgovora na tužbu. ${ }^{39}$

33 Pravno stajalište zauzeto na radnom sastanku Građanskog odjela Višeg privrednog suda u Zagrebu 3. veljače 1976. godine.

34 Borivoje Poznić, Građansko procesno pravo (Beograd: Privredna štampa, 1995.), 330.

35 Viši privredni sud Hrvatske, P̌̌-742/80 od 27. svibnja 1983.

36 Ivica Crnić, „Promjena u sustavu sporova male vrijednosti“. Informator br. 5764 (2009.): 12.

37 Visoki trgovački sud Republike Hrvatske, Pž 3441/2018-2 od 29. lipnja 2018.

38 Ministarstvo pravosuđa Republike Hrvatske, Prijedlog Zakona o izmjenama i dopunama Zakona o parničnom postupku: Obrazloženje (Zagreb: Ministarstvo pravosuđa, 2019.), 50.

39 Benzon i Vujeva, Postupak u sporovima male vrijednosti - Analiza procesnih instituta u teoriji i praksi nakon Novele Zakona o parničnom postupku iz 2013., 30. 
Najavljenu veću procesnu disciplinu stranaka zakonodavac je želio postići ponajprije novim odredbama stavaka $3 \mathrm{i} 4$. Tako je tužitelj dužan najkasnije u podnesku predanom sudu u roku od 15 dana od primitka rješenja kojim je stavljeno izvan snage rješenje o ovrsi u dijelu kojim je određena ovrha i ukinute provedene radnje, a postupak nastavljen kao u povodu prigovora protiv platnoga naloga, iznijeti sve činjenice na kojima temelji svoje zahtjeve i predložiti dokaze potrebne za utvrđivanje iznesenih činjenica. Tuženik je dužan najkasnije u roku od 15 dana od primitka tužiteljevoga podneska iznijeti sve činjenice na kojima temelji svoje zahtjeve i predložiti dokaze potrebne za utvrđivanje iznesenih činjenica. ${ }^{40}$ Problematika trenutka do kojeg se mogu iznositi činjenice i predlagati dokazi iznimno je osjetljiva i složena te je kao takva oduvijek bila predmetom brojnih praktičnih i teorijskih rasprava. Kod nekoliko zadnjih izmjena ZPP-a ta je problematika zauzimala važno mjesto. Razlog tome nalazi se u činjenici što se na području prava stranaka na iznošenje novih činjenica i novih dokaza prelamaju i suprotstavljaju neka od temeljnih načela parničnog postupka. S jedne strane, pravo na iznošenje novina omogućuje učinkovitije ostvarivanje načela traženja istine $\mathrm{i}$ donošenja zakonite odluke. $\mathrm{S}$ druge strane, to pravo negativno utječe na koncentraciju i ubrzanje postupka te slabi procesnu disciplinu stranaka. Pri regulaciji prava stranaka na iznošenje činjenica i dokaza u postupku u sporovima male vrijednosti prevaga je dana zahtjevu za uspostavom veće procesne discipline, koncentracije, učinkovitosti i ubrzavanja postupka. Time se uvelike odstupilo od općega pravila o pravu na iznošenje takve procesne građe u redovnom postupku. ${ }^{41}$

U pozivu za podnošenje pisanog odgovora na tužbu, odnosno u rješenju kojim je ukinut platni nalog, sud je dužan upozoriti stranke da su dužne: a) najkasnije u tužbi, odnosno odgovoru na tužbu; b) tužitelj najkasnije u podnesku predanom sudu u roku od 15 dana od primitka rješenja kojim je ukinut platni nalog i c) tuženik u roku od 15 dana od primitka navedenoga tužiteljevog podneska, iznijeti sve činjenice na kojima temelje svoje zahtjeve i predložiti dokaze potrebne za utvrđivanje iznesenih činjenica (arg. čl. 461.a st. 5. ZPP).

\section{NOVE ČINJENICE I DOKAZI}

Što se iznošenja novih činjenica i predlaganja novih dokaza tiče, i dalje je propisano da stranke mogu na pripremnom ročištu iznositi nove činjenice i predlagati nove dokaze samo ako ih bez svoje krivnje nisu mogle iznijeti ili predložiti u tužbi, odnosno odgovoru na tužbu. Novo je rješenje da sada stranke mogu na pripremnom ročištu iznositi nove činjenice i predlagati nove dokaze samo ako ih bez svoje krivnje nisu mogle iznijeti, odnosno predložiti u podnescima. Tužitelj najkasnije u podnesku predanom sudu u roku od 15 dana od primitka rješenja kojim je ukinut platni nalog, a tuženik u podnesku u kojemu je, u roku od 15 dana od primitka navedenog tužiteljevog podneska, mogao iznositi činjenice i predlagati dokaze (čl. 461.a st. 6. ZPP). U protivnom takve „skrivljene“ i nepravodobne nove činjenice i nove dokaze

40 Ministarstvo pravosuđa Republike Hrvatske, Prijedlog Zakona o izmjenama i dopunama Zakona o parničnom postupku: Obrazloženje, 50.

41 Bulka i Jakovina, Sporovi male vrijednosti, 9. 
koje su stranke iznijele, odnosno predložile na pripremnom ročištu, sud neće uzeti u obzir (čl. 461.a st. 7. ZPP).

Važna je novina i to da je sud dužan na pripremnom ročištu zaključiti prethodni postupak i na istom ročištu održati glavnu raspravu, osim ako to nije moguće zbog toga što su stranke pravovaljano na pripremnom ročištu iznijele nove činjenice i predložile nove dokaze (arg. čl. 461.a st. 8. ZPP).

Drži se kako je svrha novih rješenja izmijeniti psihologiju stranaka i sudaca, prisiliti stranke da najkasnije na pripremnom ročištu iznesu sve bitne činjenice i predlože sve važne dokaze kako bi se kasnija rasprava mogla ograničiti samo na izvođenje već predloženih dokaza, na utvrđivanje već iznesenih činjenica te na raspravu o rezultatima tako provedenoga postupka te da bi ograničenje mogućnosti iznošenja novina trebalo pridonijeti povećanju koncentracije u prikupljanju procesnog materijala i općoj ekspeditivnosti i učinkovitosti prvostupanjskog postupka. Ograničenjem mogućnosti iznošenja novina trebalo je poduzeti i zbog male vrijednosti sporova o kojima se odlučuje u bagatelnom postupku, što i inače opravdava njegovu sumarnost $\mathrm{i}$ ograničenost kognicije. ${ }^{42}$ Time što je propisao da se nove činjenice i dokazi mogu iznositi i nakon podnošenja tužbe i odgovora na tužbu ako ih stranka bez svoje krivnje nije mogla iznijeti prije toga, zakonodavac je uveo subjektivni element procjene postojanja ili nepostojanja krivnje one strane koja je napravila takav propust. S obzirom na to da procjena postojanja „krivnje“ uzrokuje poteškoće $\mathrm{i}$ često onemogućava uredujućeg suca da donese objektivno opravdanu odluku o njezinu postojanju ili nepostojanju, u praksi se najčešće događa da sudovi ipak prihvaćaju i činjenice i dokaze koje stranke iznesu kasnije. Smatra se kako zbog takvih vrlo čestih zloupotreba ovoga procesnog načela, sporovi male vrijednosti traju neosnovano dugo, što u konačnici ponajprije šteti vjerovniku. ${ }^{43}$

Prema stajalištu sudske prakse, u postupku u sporu male vrijednosti koji je proizašao iz rješenja o ovrsi na temelju vjerodostojne isprave tužitelj ima opravdane razloge priložiti dokaze na pripremnom ročištu jer ih bez svoje krivnje nije mogao iznijeti u prijedlogu za ovrhu. ${ }^{44} \mathrm{U}$ postupku u sporu male vrijednosti sud neće uzeti u obzir činjenice i dokaze koje tuženici nisu naveli odnosno dostavili uz prigovor protiv rješenja o ovrsi koji se smatra odgovorom na tužbu..$^{45}$

\section{ZAPISNIK}

Zapisnik je nedvojbeno javna isprava koju uredujući sud sastavlja o radnjama koje se poduzimaju u postupku koji vodi, u pravilu usmeno na ročištu (arg. čl. 123. st. 1. ZPP). Osim toga, zapisnik se može sastaviti o važnijim izjavama ili saopćenjima koje stranke ili drugi sudionici daju izvan ročišta (čl. 124. st. 1. ZPP).

Ubrzanje postupka i ostvarivanje načela ekonomičnosti nastoji se u sporovima

42 Dika, Novelirani postupak u sporovima male vrijednosti, 10.

43 Preporuke za efikasnije vođenje sporova male vrijednosti (Zagreb: Američka gospodarska komora u Hrvatskoj, 2017.), 5.

44 Županijski sud u Varaždinu, Gž-654/2017-2 od 27. studenog 2017.

45 Županijski sud u Varaždinu, Gž-1550/2017-2 od 17. kolovoza 2018. 
male vrijednosti ostvariti i time što se sadržaj raspravnog zapisnika ograničava na ono što je najnužnije. U zapisnik o ročištu u sporovima male vrijednosti unose se prije svega podatci koji se unose i u zapisnik o glavnoj raspravi u redovitom postupku, a to su: naziv i sastav suda, mjesto gdje se obavlja radnja, dan i sat kad se obavlja radnja, naznaka predmeta spora i imena nazočnih stranaka, odnosno trećih osoba, i njihovih zakonskih zastupnika odnosno punomoćnika (čl. 124. st. 1. ZPP). Sadržaj zapisnika u sporovima male vrijednosti reduciran je, međutim, u opsegu unošenja izjava stranaka, sadržaju izvedenih dokaza i drugih podataka. Tako, prema odredbama čl. 463. ZPP-a, zapisnik o ročištu, osim spomenutih podataka iz čl. 124. st. 1. ZPP-a, sadrži: izjave stranaka od bitnog značenja, a osobito one kojima se, u cijelosti ili djelomično, priznaje tužbeni zahtjev, ili se odriče od tužbenog zahtjeva ili od žalbe, ili se preinačava ili povlači tužba; bitni sadržaj izvedenih dokaza; odluke protiv kojih je dopuštena žalba i koje su objavljene na ročištu; jesu li stranke bile nazočne objavi presude i, ako su bile nazočne, da su poučene uz koje uvjete mogu podnijeti žalbu.

\section{POSLJEDICE IZOSTANKAS PRIPREMNOG ROČIŠTA}

Odredbama čl. 94. Novele u cijelosti je izmijenjen dotadašnji čl. 465. ZPP-a. Ovim člankom Novele usklađuju se pravila o neaktivnosti stranka na drugom ili kasnijem ročištu s obzirom na to pravilo da bi postupak trebalo pred prvim stupnjem provesti na jednom pripremnom i na jednom ročištu za glavnu raspravu. ${ }^{46}$

Odredbama dotadašnjega čl. 465. ZPP-a bilo je propisano da, ako tužitelj ne dođe na prvo ročište, a uredno je pozvan, trebalo se smatrati da je povukao tužbu, osim ako se tuženik na tom ročištu ne bi upustio u raspravu. Ako bi s kojega kasnijeg ročišta izostale obje stranke, sud je bio dužan odgoditi ročište. Ako i na novo ročište ne bi došle obje stranke, smatralo se da je tužitelj povukao tužbu. Sud je u pozivu za odgovor na tužbu trebao, između ostalog, upozoriti stranke da će se smatrati da je tužitelj povukao tužbu ako ne dođe na prvo ročište, da u tom postupku stranke trebaju iznijeti sve činjenice i predložiti sve dokaze najkasnije u tužbi, odnosno odgovoru na tužbu, da na pripremnom ročištu ne mogu iznositi nove činjenice i predlagati nove dokaze, osim u slučaju iz čl. 461.a st. 3. ZPP-a te da se odluka može pobijati samo zbog bitnih povreda odredaba parničnog postupka iz čl. 354. st. 2. t. 1., 2., 4., 5., 6., 8., 9., 10. i 11. ZPP-a i zbog pogrešne primjene materijalnog prava.

Prema odredbi noveliranoga čl. 465. st. 1. ZPP-a, ako tužitelj ne dođe na pripremno ročište (ranije, na prvo ročište), a uredno je pozvan, smatrat će se da je povukao tužbu, osim ako se tuženik na tom ročištu ne upusti u raspravu. Riječ je o prisilnoj odredbi iz koje se izvodi neoboriva pretpostavka o povlačenju tužbe. ${ }^{47}$ Presumpcija o povlačenju tužbe je neoboriva i činjenica koja se presumira jest da je nastupila pravna posljedica povlačenja tužbe ex lege, a ne da je tužitelj dao ili trebao dati izjavu da povlači tužbu s kojom bi se tuženik tek trebao suglasiti da bi došlo do

46 Ministarstvo pravosuđa Republike Hrvatske, Prijedlog Zakona o izmjenama $i$ dopunama Zakona o parničnom postupku: Obrazloženje, 50.

47 Visoki trgovački sud Republike Hrvatske, Pž-6068/2017-2 od 16. listopada 2017. 
pravne posljedice povlačenja tužbe (vidi čl. 193. ZPP). ${ }^{48}$ Kada se ispuni ta zakonska pretpostavka, tužba se smatra povučenom po samom zakonu, a odluka suda o tome je deklaratorne prirode, jer sud samo utvrđuje činjenicu koja je već nastupila ex lege. ${ }^{49}$

Nisu ispunjeni uvjeti za donošenje rješenja kojim se utvrđuje da je tužba povučena ako je tužitelj bio nazočan na prvom pripremnom ročištu na kojemu se tuženik upustio u raspravljanje. ${ }^{50}$ Presumpcija povlačenja tužbe u postupku u sporu male vrijednosti zbog nedolaska tužitelja na pripremno ročište, postoji samo ako je tužitelj bio uredno pozvan. ${ }^{51}$ On, međutim, nije bio uredno pozvan ako u pozivu za pripremno ročište nije bio upozoren na navedenu posljedicu svoga izostanka s ročišta. ${ }^{52}$ Uručenje poziva tužitelju bez prethodnog upozorenja na posljedice nedolaska na pripremno ročište ne smatra se urednom dostavom u sporu male vrijednosti, pa se ne može donijeti rješenje o povlačenju tužbe zbog nedolaska tužitelja na to zakazano ročište. ${ }^{53} \mathrm{Da}$ bi se donijelo rješenje o presumpciji povlačenja tužbe zbog nedolaska tužitelja na pripremno ročište (čl. 465. st. 1. ZPP), nije dostatno da je poziv uredno dostavljen nego i da je ročište određeno tako da stranke imaju dostatno vremena za pripremu, a najmanje osam dana od primitka poziva. ${ }^{54}$

Smatra se da tužitelj nije pristupio na (prvo) pripremno ročište u sporu male vrijednosti kada zamjenik punomoćnika pristupi na ročište bez valjane punomoći, a u ostavljenom roku ne dostavi punomoć za zastupanje. ${ }^{55}$ Tužba se smatra povučenom i onda kad je za tužitelja na pripremno ročište u sporu male vrijednosti pristupila osoba bez punomoći koja nije i u ostavljenom roku podnijela punomoć. ${ }^{56}$ Ako je tužbu podnio odvjetnik koji nije naveden kao punomoćnik, a potpisala ju je stranka, dostava je uredna ako je izvršena neposredno stranci. ${ }^{57}$ Kada u sporovima male vrijednosti na pripremnom ročištu za tužitelja pristupi odvjetnik bez punomoći, sud ne može odmah donijeti odluku kojom uskraćuje zastupanje tom odvjetniku i odluku o presumiranom povlačenju tužbe, već je obvezan dopustiti da radnje u postupku za tužitelja privremeno obavi odvjetnik bez punomoći, ali će mu istodobno narediti da $u$ određenom roku podnese punomoć ili odobrenje stranke za obavljene parnične radnje. Tek ako se taj nedostatak u zastupanju naknadno ne otkloni, sud može donijeti odluku o presumiranom povlačenju tužbe. ${ }^{58}$ Donošenje rješenja o presumiranom povlačenju tužbe zbog nepristupanja tužitelja na ročište temelji se na činjenici potpune pasivnosti tužitelja. Ta pretpostavka nije ostvarena onda kada za tužitelja na to ročište pristupi osoba punomoćnika (odvjetnik) makar i bez uredne (potpisane) punomoći ako ona zatraži dozvolu zastupanja od suda uz obvezu naknadne dostave valjane punomoći u

48 Županijski sud u Varaždinu, Gž-700/2017-5 od 4. rujna 2018.

49 Visoki trgovački sud Republike Hrvatske, Pž-6946/2015-2 od 16. svibnja 2018.

50 Županijski sud u Varaždinu, Gž-1552/16-2 od 16. ožujka 2017.

51 Viši privredni sud Hrvatske, Pž-1051/80. od 22. srpnja 1980.

52 Vrhovni sud Hrvatske, Gzz-37/92. od 15. prosinca 1992.

53 Viši privredni sud, Pž-334/72. od 14. veljače 1973.

54 Vrhovni sud Kosova, Pž-51/79. od 13. srpnja 1979.

55 Županijski sud u Dubrovniku, Gž-1609/14, od 18. ožujka 2014.

56 Viši privredni sud Hrvatske, Pž-2400/90. od 11. prosinca 1990.

57 Viši privredni sud, Pž-116/82. od 25. siječnja 1982.

58 Visoki trgovački sud Republike Hrvatske, Pž-2962/06 od 2. srpnja 2008. 
po sudu određenom joj roku. ${ }^{59}$

Odredbama čl. 94. Novele mijenja se i upozorenje koje je sud dužan dati strankama u pozivu za prvo ročište. ${ }^{60}$ Sud je u pozivu za pripremno ročište, među ostalim, dužan upozoriti stranke da će se smatrati da je tužitelj povukao tužbu ako ne dođe na pripremno ročište, da na pripremnom ročištu ne mogu iznositi nove činjenice i predlagati nove dokaze, osim ako ih bez svoje krivnje nisu mogle iznijeti, odnosno predložiti u tužbi, odgovoru na tužbu ili u podnescima u povodu rješenja kojim je ukinut platni nalog (iz čl. 461.a st. 6. ZPP-a), da će na pripremnom ročištu zaključiti prethodni postupak i na istom ročištu održati glavnu raspravu, osim ako zbog navedenih okolnosti slučaja iz čl. 461.a st. 6 ZPP-a to ne bude moguće te da se odluka može pobijati samo zbog pogrešne primjene materijalnog prava i zbog bitnih povreda odredaba parničnog postupka iz čl. 354. st. 2. ZPP-a, osim zbog povrede iz čl. 354. st. 2. t. 3. ZPP-a, odnosno ako je sud u povodu prigovora stranaka pogrešno odlučio da je stvarno ili mjesno nadležan.

Člankom 117. st. 2. Novele propisana je primjena odredaba čl. 94. Novele, a time i odredaba noveliranog čl. 465. ZPP-a, na sve postupke u tijeku.

Odredbom čl. 95. Novele brisan je u potpunosti čl. 466. ZPP-a. Njome se ukida posebno pravilo o objavi presude u sporovima male vrijednosti odmah nakon zaključenja glavne rasprave ${ }^{61}$ Smatralo se da je riječ o nepotrebno strogoj odredbi budući da se njome, na neki način, prisiljava stranke da su fizički prisutne na objavljivanju presude i davanju pouke o uvjetima uz koje mogu podnijeti žalbu, čime su stranke bile izložene dodatnim troškovima. ${ }^{62}$ Naime, prema dosadašnjoj odredbi čl. 466. ZPP-a bilo je propisano da se presuda u postupku u sporovima male vrijednosti objavljuje odmah nakon zaključenja glavne rasprave. Pri objavi presude sud je bio dužan poučiti prisutne stranke o uvjetima uz koje mogu podnijeti žalbu (čl. 467. ZPP-a). Za razliku od redovitog postupka u kojemu se presuda, u pravilu, donosi i objavljuje odmah po zaključenju glavne rasprave, a u složenijim predmetima sud može odgoditi donošenje presude za osam dana od zaključenja glavne rasprave (čl. 335. ZPP), u postupku u sporovima male vrijednosti presuda se uvijek objavljivala odmah po zaključenju glavne rasprave ${ }^{63}$ Presuda se objavljivala na način da bi sudac koji je presudu donio javno pročitao izrijeku presude i priopćio ukratko razloge presude (čl. 336. st. 1. ZPP), a zatim bi poučavao prisutne o uvjetima pod kojima mogu izjaviti žalbu (čl. 467. ZPP).

Člankom 117. st. 2. Novele propisana je primjena odredaba čl. 95. Novele o brisanju čl. 466. ZPP-a na sve postupke u tijeku.

59 Županijski sud u Bjelovaru, Gž-666/16-2 od 25. listopada 2017.

60 Ministarstvo pravosuđa Republike Hrvatske, Prijedlog Zakona o izmjenama $i$ dopunama Zakona o parničnom postupku: Obrazloženje, 50.

61 Ministarstvo pravosuđa Republike Hrvatske, Prijedlog Zakona o izmjenama i dopunama Zakona o parničnom postupku: Obrazloženje, 50.

62 Ivica Crnić, „Promjena u sustavu sporova male vrijednosti: 2. dio“, Informator br. 5765 (2009.): 8.

63 "Presuda donesena u postupku u sporovima male vrijednosti mora biti objavljena odmah nakon zaključenja glavne rasprave”, Viši privredni sud Hrvatske, Pž-58/87. od 15. prosinca 1987. 


\section{PRAVNI LIJEKOVI}

U postupku u sporovima male vrijednosti dopuštena je posebna žalba samo protiv rješenja kojim se završava postupak. Ostala rješenja protiv kojih je po ovom zakonu dopuštena žalba mogu se pobijati samo žalbom protiv odluke kojom se postupak završava, a ta se rješenja ne dostavljaju strankama, već se objavljuju na ročištu i unose u pismeni sastav odluke (čl. 462. ZPP). ${ }^{64}$ Iako iz odredbe čl. 462. ZPP-a proizlazi da u sporovima male vrijednosti nije dopuštena posebna žalba na rješenja kojima se ne dovršava postupak, već se ona pobijaju žalbom na odluku kojom se postupak dovršava, tu odredbu treba tumačiti na način da se ona odnosi na postupke u kojima je rješenje (kojim se ne završava postupak) doneseno prije odluke kojom se postupak završava. Naime, po prirodi stvari, rješenje doneseno prije odluke kojom se postupak dovršava može biti uneseno u pisani sastav odluke, pa se stranke mogu žaliti na takvo rješenje jer im je poznato da postoji i poznat im je sadržaj. U protivnom, kada se rješenje kojim se ne završava postupak donese nakon što se donese odluka o glavnoj stvari, ono nije moglo biti uneseno u pisani sastav odluke o glavnoj stvari. U takvoj se situaciji primjenjuju druge odredbe ZPP-a, na temelju odredbe čl. 457. ZPP-a, a to znači da se rješenje dostavlja stranci i ona ima pravo posebne žalbe protiv. ${ }^{65}$

Člankom 96. Novele u cijelosti je izmijenjen dotadašnji čl. 467. ZPP-a. na način da se navedenom odredbom Novele mijenjaju žalbeni razlozi iz kojih se može pobijati odluka kojom se završava spor u postupku u sporovima male vrijednosti. ${ }^{66}$

Prema odredbama dotadašnjega čl. 467. st. 1. ZPP-a, presuda ili rješenje kojim se završava spor u postupku u sporovima male vrijednosti mogli su se pobijati samo zbog bitne povrede odredaba parničnog postupka iz čl. 354. st. 2. t. 1., 2., 4., 5., 6., 8., 9., 10. i 11. ovoga zakona i zbog pogrešne primjene materijalnog prava.

Na temelju novelirane odredbe čl. 467. st. 1. ZPP-a presuda ili rješenje kojim se završava spor u postupku u sporovima male vrijednosti može se pobijati samo zbog pogrešne primjene materijalnog prava i zbog bitnih povreda odredaba parničnog postupka iz čl. 354. st. 2. ovoga Zakona, osim zbog povrede iz čl. 354. st. 2. t. 3. ovoga Zakona. Drugim riječima, proširen je krug žalbenih razloga u odnosu na bitne povrede odredaba parničnog postupka jer se do sada nije mogla izjaviti u sljedećim slučajevima:

- ako je protivno odredbama ovoga Zakona sud odbio zahtjev stranke da se u postupku služi svojim jezikom i pismom i da prati tijek postupka na svom jeziku, a stranka se zbog toga žali,

- ako je presudom prekoračen tužbeni zahtjev,

- ako je odlučeno u povodu nepravodobno podnesene tužbe, a zbog toga je tužbu trebalo odbaciti i

64 „Rješenje suda kojim se u sporu male vrijednosti zaključuje prethodni postupak nije rješenje kojim se završava postupak. Zbog toga, protiv tog rješenja stranke ne mogu podnijeti posebnu žalbu, već tu odluku mogu pobijati samo u žalbi protiv odluke kojom se završava postupak.“ Visoki trgovački sud Republike Hrvatske, Pž-6830/09 od 18. lipnja 2010.

65 Županijski sud u Dubrovniku, Gž-565/16, od 14. prosinca 2016.

66 Ministarstvo pravosuđa Republike Hrvatske, Prijedlog Zakona o izmjenama $i$ dopunama Zakona o parničnom postupku: Obrazloženje, 50. 
- ako prije podnošenja tužbe nije proveden zakonom predviđeni postupak mirnog ili drukčijeg ostvarivanja prava, a zbog toga je tužbu trebalo odbaciti. Dakle u postupcima male vrijednosti koji su pokrenuti nakon 1. rujna 2019. moći će se izjavljivati žalba i iz prethodno navedena četiri razloga, što nakon novele 2013. nije bilo moguće, a to je posebno u slučajevima prekoračenja tužbenog zahtjeva bilo vrlo nelogično rješenje. Naime, sve do žalbe stranke nisu niti mogle znati da će sud prekoračiti tužbeni zahtjev, a žalba im nije bila omogućena. ${ }^{67}$

Može se zaključiti da se, de lege lata, presuda ili rješenje kojim se završava spor u postupku u sporovima male vrijednosti može pobijati samo zbog pogrešne primjene materijalnog prava i zbog (apsolutno) bitnih povreda odredaba parničnog postupka: ako je u donošenju presude sudjelovao sudac koji se po zakonu mora izuzeti (čl. 71. st. 1. t. 1. do 6.), odnosno koji je rješenjem suda bio izuzet, ili ako je u donošenju presude sudjelovala osoba koja nema svojstvo suca; ako je odlučeno o zahtjevu u sporu koji ne ide u sudsku nadležnost (čl. 16.); ako je protivno odredbama ovoga Zakona sud utemeljio svoju odluku na nedopuštenim raspolaganjima stranaka (čl. 3. st. 3.); ako je protivno odredbama ovoga Zakona donio presudu na temelju priznanja, presudu na temelju odricanja, presudu zbog ogluhe, presudu zbog izostanka ili presudu bez održavanja rasprave; ako kojoj stranci nezakonitim postupanjem, a osobito propuštanjem dostave, nije dana mogućnost da raspravlja pred sudom; ako je protivno odredbama ovoga Zakona sud odbio zahtjev stranke da se u postupku služi svojim jezikom i pismom i da prati tijek postupka na svom jeziku, a stranka se zbog toga žali; ako je u postupku kao tužitelj ili tuženik sudjelovala osoba koja ne može biti stranka u postupku, ili ako stranku koja je pravna osoba nije zastupala ovlaštena osoba, ili ako parnično nesposobnu stranku nije zastupao zakonski zastupnik, ili ako zakonski zastupnik, odnosno punomoćnik stranke nije imao potrebno ovlaštenje za vođenje parnice ili za pojedine radnje u postupku, ako vođenje parnice, odnosno obavljanje pojedinih radnji u postupku nije bilo naknadno odobreno; ako je odlučeno o zahtjevu o kojemu već teče parnica, ili o kojemu je već prije pravomoćno presuđeno, ili o kojemu je već zaključena sudska nagodba ili nagodba koja po posebnim propisima ima svojstvo sudske nagodbe; ako je protivno zakonu bila isključena javnost na glavnoj raspravi; ako presuda ima nedostataka zbog kojih se ne može ispitati, a osobito ako je izrijeka presude nerazumljiva, ako proturječi sama sebi ili razlozima presude, ili ako presuda nema razloga o odlučnim činjenicama, ili ako o odlučnim činjenicama postoji proturječnost između onoga što se $u$ razlozima presude navodi o sadržaju isprava ili zapisnika o iskazima danim u postupku i samih tih isprava ili zapisnika; ako je presudom prekoračen tužbeni zahtjev; ako je odlučeno u povodu nepravodobno podnesene tužbe, a zbog toga je tužbu trebalo odbaciti (čl. 282. st. 1.) te ako prije podnošenja tužbe nije proveden zakonom predviđeni postupak mirnog ili drukčijeg ostvarivanja prava, a zbog toga je tužbu trebalo odbaciti.

A contrario, presuda ili rješenje kojim se završava spor u postupku u sporovima male vrijednosti ne bi se mogli pobijati žalbom zbog pogrešno ili nepotpuno utvrđenoga činjeničnog stanja (čl. 355. ZPP); zbog relativno bitnih povreda odredaba

67 Čuveljak, Sporovi male vrijednosti prema noveli Zakona o parničnom postupku 2019. 
parničnog postupka (čl. 354. st. 1. ZPP) te zbog toga što je sud u povodu prigovora stranaka pogrešno odlučio da je stvarno ili mjesno nadležan (čl. 354. st. 2. t. 3. ZPP) ${ }^{68}$

Odredba st. 2. ostala je neizmijenjena pa se i dalje propisuje da se u postupku u povodu žalbe u sporovima male vrijednosti ne primjenjuju odredbe čl. 370. ZPP-a. Naime, odredbom navedenoga članka propisano je da će drugostupanjski sud rješenjem ukinuti presudu prvostupanjskog suda i vratiti predmet tom sudu na ponovno suđenje ako smatra da radi pravilnog utvrđivanja činjeničnog stanja treba održati novu glavnu raspravu pred prvostupanjskim sudom. Kako ZPP u postupku u sporovima male vrijednosti zabranjuje primjenu općih pravila o ukidanju odluke zbog nepravilno (pogrešno ili nepotpuno) utvrđenog činjeničnog stanja, žalbu u kojoj se iznose ti razlozi (zbog kojih se žalba ne može podnijeti), treba odbaciti kao nedopuštenu. I u sudskoj praksi je neprijeporno da se protiv presude kojom se završava spor male vrijednosti, žalba ne može podnijeti iz razloga pogrešno i nepotpuno utvrđenoga činjeničnog stanja. ${ }^{69}$ Tako je, prema stajalištu sudske prakse, u postupku u sporu male vrijednosti nedopuštena žalba u kojoj je kao jedini žalbeni razlog izneseno pogrešno ili nepotpuno utvrđeno činjenično stanje. ${ }^{70}$ Dakle, ako u sporu male vrijednosti stranka uloži žalbu samo zbog nepotpuno utvrđenoga činjeničnog stanja i u njoj predloži ukidanje prvostupanjske odluke radi izvođenja novih dokaza, takvu žalbu treba odbaciti kao nedopuštenu, jer se iz tih razloga odluka donesena u sporu male vrijednosti ne može pobijati. ${ }^{71}$ Kako se u sporovima male vrijednosti presuda ne može pobijati zbog pogrešno i nepotpuno utvrđenoga činjeničnog stanja, to znači da je drugostupanjski sud kod odlučivanja o žalbi vezan za činjenični supstrat spora koji je utvrdio prvostupanjski sud. ${ }^{72}$

I odredba prijašnjeg st. 6. a sada st. 3., ostala je neizmijenjena pa se i dalje propisuje da o žalbi protiv presude u sporovima male vrijednosti odlučuje sudac pojedinac drugostupanjskog suda. Postupak drugoga stupnja po žalbi istovjetan je redovnom postupku, osim što je pripisano da o žalbi protiv presude u sporovima male vrijednosti odlučuje sudac pojedinac drugostupanjskog suda. Dakle, u ovoj vrsti postupka i u prvom i u drugom stupnju uvijek sudi sudac pojedinac. ${ }^{73}$

Vidljivo je da su odredbom čl. 96. Novele brisane odredbe st. 3., 4. i 5. dotadašnjega čl. 467. ZPP-a, prema kojima su protiv prvostupanjske presude odnosno rješenje kojim se završava spor u postupku u sporovima male vrijednosti, stranke mogle podnijeti žalbu u roku od osam dana, a rok za žalbu računao se od dana objave presude odnosno rješenja, a ako su presuda, odnosno rješenje bili dostavljeni stranci, rok se računao od dana dostave. U postupku u sporovima male vrijednosti rok iz čl.

68 „U postupku pred trgovačkim sudom, u sporovima male vrijednosti, prvostupanjska odluka se ne može pobijati zbog žalbenog razloga pogrešno i nepotpuno utvrđenog činjeničnog stanja“. Visoki trgovački sud Republike Hrvatske, Pž-4479/2015-2 od 28. kolovoza 2018. „U sporu male vrijednosti nije dopušteno isticati žalbeni razlog bitne povrede odredaba parničnog postupka koji se odnosi na prekoračenje tužbenog zahtjeva“. Županijski sud u Varaždinu, Gž1869/2018-2 od 22. veljače 2019.

69 Okružni sud u Sisku, Gž-140/80. od 12. veljače 1980.

70 Viši privredni sud Hrvatske, Pž-598/79. od 6. lipnja 1983.

71 Viši privredni sud Hrvatske, Pž-4829/77. i Pž-4794/77.

72 Županijski sud u Splitu, Gž-2089/15, od 22. ožujka 2016.

73 Jelena Čuveljak, Sporovi male vrijednosti prema noveli Zakona o parničnom postupku 2019. 
328. st. 2. i čl. 339. st. 1. ovoga zakona bio je osam dana. Navedeni stavci morali su biti ukinuti jer su zbog ostalih odredbi Novele, a poglavito odredbe čl. 95. kojom je brisan dotadašnji čl. 466. ZPP-a o obveznom objavljivanju presude odmah nakon zaključenja glavne rasprave, postali nepotrebni, odnosno neprimjenjivi.

Ova se nova pravila o razlozima za žalbu primjenjuju u svim postupcima pokrenutim nakon 1. rujna 2019.

U sporovima male vrijednosti može se dopustiti ponavljanje postupka u smislu odredaba čl. 421. t. 9. ZPP-a, odnosno postupak koji je odlukom suda pravomoćno završen može se na prijedlog stranke ponoviti ako stranka sazna za nove činjenice ili nađe ili stekne mogućnost da upotrijebi nove dokaze na temelju kojih je za stranku mogla biti donesena povoljnija odluka da su te činjenice ili dokazi bili upotrijebljeni u prijašnjem postupku. ${ }^{74}$ Ovi razlozi ukazuju da je zbog nepotpuno ili pogrešno utvrđenoga činjeničnog stanja sud, u prijašnjem postupku, donio nepravilnu odluku. Pritom je do tako nevaljanoga činjeničnog stanja, koje je sud uzeo za temelj svoga suđenja, došlo jer stranka u prijašnjem postupku nije uspjela dokazati određenu činjeničnu osnovu na kojoj je temeljila svoj zahtjev ili je pobijala činjeničnu osnovu zahtjeva protivne stranke ili nije uspjela dokazati određene okolnosti koje uzrokuju, primjerice, odbacivanje tužbe protivne stranke. Sve to iz razloga što u ranijem postupku stranka nije znala za postojanje ili nastanak određenih činjenica ili dokaze kojima bi se utvrdile te činjenice, ili u ranijem postupku nije mogla upotrijebiti određeni dokaz u tu svrhu. ${ }^{75}$

Vrlo važna izmjena koju je u parnični postupak unijela Novela odnosi se na to da u sporovima male vrijednosti žalba protiv presude ili rješenja više ne odgađa ovrhu, osim ako sud po službenoj dužnosti, i to iznimno, odredi drukčije. ${ }^{76}$ Naime, odredbom čl. 97. Novele u cijelosti je izmijenjen dotadašnji čl. 467.a ZPP-a tako da je propisano kako u postupku u sporovima male vrijednosti žalba protiv presude ili rješenja ne odgađa ovrhu, osim ako sud koji donosi presudu ili rješenje, iznimno, po službenoj dužnosti, obrazloženim rješenjem, odredi drukčije. ${ }^{77}$ Dakle, u pravilu, žalba nije više suspenzivna.

74 Stajalište zauzeto na koordinacijskom sastanku privrednog sudstva SFR Jugoslavije održanom u svibnju 1984.

75 Branko Hrvatin, „Nove činjenice i novi dokazi kao razlog za ponavljanje postupka “, u: Aktualnosti hrvatskog zakonodavstva i pravne prakse - Godišnjak 1 (Zagreb: Organizator, 1994.), 338.

76 Ovom se odredbom propisuje da u sporovima male vrijednosti žalba protiv presude ili rješenja ne odgađa ovrhu, osim ako sud koji donosi presudu ili rješenje, iznimno, po službenoj dužnosti, obrazloženim rješenjem, odredi drukčije. Ministarstvo pravosuđa Republike Hrvatske, Prijedlog Zakona o izmjenama i dopunama Zakona o parničnom postupku: Obrazloženje, 50. Tijekom javnoga savjetovanja bilo je primjedbi kako se „ovakvom odredbom otežava položaj strankama i otvara se mogućnost subjektivnog, neograničenog diskrecijskog odlučivanja odnosno arbitrarnosti (samovolje) u odlučivanju. Držalo se da nedostaju jasni kriteriji po kojima bi sud „odredio drukčije“, odnosno odredio da žalba protiv presude ili rješenja odgađa ovrhu (Hrvatska odvjetnička komora), odnosno smatralo se da nisu jasni kriteriji kada i pod kojim uvjetima sud koji donosi presudu ili rješenje može „odrediti drugačije“ (primjedba: Porobija \& Špoljarić d.o.o.).

77 „Ako ocijeni da za to postoje opravdani razlozi sud je ovlašten odrediti - bilo izrekom odluke na koju se odnosi bilo u uputi o pravnom lijeku protiv te odluke, i onda kada za to ne postoji prijedlog stranke, da izjavljena žalba ne zadržava provedbu ovrhe donesene odluke.“ Županijski sud u Bjelovaru, Gž R-270/16-7 od 12. listopada 2017. 
Druga je važna novina koju je u odredbe dotadašnjega čl. 467.a ZPP-a unijela Novela da nema više revizije po dopuštenju drugostupanjskog suda. Do stupanja na snagu Novele protiv odluke drugostupanjskog suda dopuštena je bila samo, tzv. izvanredna revizija iz čl. 382. st. 2. ZPP-a (vidi čl. 467. st. 7., odnosno 467.a ex ZPP). Dakle, samo ako je drugostupanjski sud u izrijeci svoje presude odredio da je revizija protiv nje dopuštena, a drugostupanjski sud je mogao tako odlučiti ako bi ocijenio da odluka o sporu ovisi o rješenju nekog materijalno-pravnog ili postupovnopravnog pitanja važnog za osiguravanje jedinstvene primjene prava i ravnopravnosti svih u njegovoj primjeni. Smatralo se je da se i u sporovima male vrijednosti mogu postaviti i te kako značajna, složena pa i načelna pravna pitanja, koja se mogu odraziti na cjelokupnu sudsku praksu te stoga i tim revizijama Vrhovni sud mora dati punu pozornost. ${ }^{78}$ Iz odredbi čl. 488. i čl. 457. st. 1. ZPP-a proizlazi da se u posebnim postupcima, u postupku u sporovima male vrijednosti i u postupku pred trgovačkim sudovima, ponajprije primjenjuju odredbe ZPP-a o njima, a supsidijarno se primjenjuju opće odredbe ZPP-a. Iz navedenoga se moglo zaključiti da se kod odlučivanja o dopuštenosti revizije u postupku pred trgovačkim sudom u sporu male vrijednosti trebalo uzeti u obzir odredbe čl. 467., odnosno 467.a ZPP-a, a ne opća odredba iz čl. 382. st. 1. t. 3. ZPP-a. Navedeno je shvaćanje vrijedilo za sve drugostupanjske presude donesene na temelju odredbe čl.373.a ZPP-a u postupku u sporu male vrijednosti i kada nije bila riječ o postupku pred trgovačkim sudovima. Pritom je nužno napomenuti da je tada za određivanje je li riječ o sporovima male vrijednosti ili ne, bila mjerodavna vrijednost predmeta spora od 10.000,00 kuna, a ne od 50.000,00 kuna. ${ }^{79}$ Dakle, kada je u postupku pred trgovačkim sudom u postupku u sporu male vrijednosti drugostupanjska presuda bila donesena na temelju odredbe čl. 373.a ZPP-a, za odlučivanje o dopuštenosti revizije mjerodavna je bila posebna odredba čl. 467.a st. 1. ZPP-a kojom je uređen postupak u sporovima male vrijednosti, a ne opća odredba čl. 382. st. 1. t. 3. ZPP-a. ${ }^{80}$

Nakon stupanja na snagu Novele, stranke mogu podnijeti reviziju protiv presude donesene u postupku u sporovima male vrijednosti u drugom stupnju ako bi Vrhovni sud Republike Hrvatske dopustio podnošenje takve revizije (arg. čl. 382. st. 1. ZPP), uz odgovarajuću primjenu odredbi kojima su uređeni uvjeti za izjavljivanje revizije i postupak odlučivanja o reviziji.

Člankom 117. st. 3. Novele propisana je primjena odredaba čl. 97. Novele, odnosno odredaba noveliranoga čl. 467.a na sve postupke u tijeku u kojima do 1 . rujna 2019. nije donesena prvostupanjska odluka.

78 Ivica Crnić, „Promjena u sustavu sporova male vrijednosti: 2. dio“, Informator br. 5765 (2009): 10.

79 Ante Drezga, Dopuštenost tzv. redovne revizije protiv drugostupanjske presude donesene prema odredbi članka 373.a Zakona o parničnom postupku, IUS-INFO, pristup 27.12.2019., http:// www.iusinfo.hr/Article/Content.aspx?SOPI=CLN20V01D2017B1062\&Doc=CLANCI_HR

80 Vrhovni sud Republike Hrvatske, Revt 258/2013-2 od 28.5.2014. „S obzirom da drugostupanjski sud u izreci pobijane presude, donesene u sporu male vrijednosti, nije odredio da je protiv nje dopuštena revizija iz čl. 382. st. 2. ZPP, to podnesena revizija tužitelja nije dopuštena u smislu odredbe čl. 467.a ZPP. Stoga je valjalo reviziju tužitelja odbaciti na temelju odredbe čl. 392.b st. 1. u vezi čl. 467.a. ZPP-a“. Vrhovni sud Republike Hrvatske, Rev-310/2016-2 od 18. srpnja 2018. 


\section{ZAKLJUČAK}

Prije ili kasnije, nakon proteka određenog razdoblja primjene odredaba ZPP-a u praksi, nužno je i korisno sagledati učinke primjene pojedinih odredbi te, u slučaju uočavanja problema i nejasnoća provesti i reformu odredaba parničnog zakona. U pravilu se sve reforme parničnog zakona provode kako bi parnični postupak bio brži i jeftiniji pa time i učinkovitiji, a sve kako bi stranke mogle što prije ostvariti i zaštititi svoja povrijeđena i/ili ugrožena prava. Vidjeli smo da su se u svakoj reformi parničnog zakona koje su provedene u zadnjih petnaestak godina, uvijek reformirale i odredbe kojima se uređuje postupak u sporovima male vrijednosti. Ponajviše zbog toga što je osnovna svrha odredaba koje uređuju postupak u sporovima male vrijednosti upravo omogućavanje bržeg, učinkovitijeg i jednostavnijeg rješavanja predmeta koji svojim brojem opterećuju sudove, a čija visina nije takva da bi zahtijevala veće angažiranje stranaka i suda. Tako su i Novelom u postupak u sporovima male vrijednosti unesene bitne izmjene relevantnih odredaba ZPP-a.

Člankom 93. Novele u cijelosti je izmijenjen čl. 461.a ZPP-a. Zakonodavac je ovim člankom želio propisati veću procesnu disciplinu stranaka u postupku u sporovima male vrijednosti. Najavljenu veću procesnu disciplinu stranaka zakonodavac je želio postići ponajprije novim odredbama st. 3. i 4. Tako je tužitelj dužan najkasnije u podnesku predanom sudu u roku od 15 dana od primitka rješenja kojim je stavljeno izvan snage rješenje o ovrsi u dijelu kojim je određena ovrha $i$ ukinute provedene radnje, a postupak nastavljen kao u povodu prigovora protiv platnoga naloga, iznijeti sve činjenice na kojima temelji svoje zahtjeve i predložiti dokaze potrebne za utvrđivanje iznesenih činjenica. Tuženik je dužan najkasnije u roku od 15 dana od primitka tužiteljevog podneska iznijeti sve činjenice na kojima temelji svoje zahtjeve i predložiti dokaze potrebne za utvrđivanje iznesenih činjenica.

I dalje je propisano da stranke mogu na pripremnom ročištu iznositi nove činjenice i predlagati nove dokaze samo ako ih bez svoje krivnje nisu mogle iznijeti, odnosno predložiti u tužbi, odnosno odgovoru na tužbu. Novina je da sada stranke mogu na pripremnom ročištu iznositi nove činjenice i predlagati nove dokaze samo ako ih bez svoje krivnje nisu mogle iznijeti, odnosno predložiti u podnescima. Tužitelj najkasnije u podnesku predanom sudu u roku od 15 dana od primitka rješenja kojim je ukinut platni nalog, a tuženik u podnesku u kojemu je, u roku od 15 dana od primitka navedenog tužiteljevog podneska, mogao iznositi činjenice i predlagati dokaze (čl. 461.a st. 6. ZPP). U protivnom takve, ,skrivljene“ i nepravodobne nove činjenice i nove dokaze koje su stranke iznijele, odnosno predložile na pripremnom ročištu sud neće uzeti u obzir (čl. 461.a st. 7. ZPP). Važna je novina i to da je sud dužan na pripremnom ročištu zaključiti prethodni postupak i na istom ročištu održati glavnu raspravu, osim ako to nije moguće zbog toga što su stranke pravovaljano na pripremnom ročištu iznijele nove činjenice i predložile nove dokaze (arg. čl. 461.a st. 8. ZPP).

Odredbama čl. 94. Novele u cijelosti je izmijenjen dotadašnji čl. 465. ZPP-a. Ovim člankom Novele usklađuju se pravila o neaktivnosti stranka na drugom ili kasnijem ročištu s obzirom na to pravilo da bi postupak trebalo pred prvim stupnjem provesti na jednom pripremnom i na jednom ročištu za glavnu raspravu. Prema 
odredbi noveliranoga čl. 465. st. 1. ZPP-a, ako tužitelj ne dođe na pripremno ročište (ranije, na prvo ročište), a uredno je pozvan, smatrat će se da je povukao tužbu, osim ako se tuženik na tom ročištu ne upusti u raspravljanje. Riječ je o prisilnoj odredbi iz koje se izvodi neoboriva pretpostavka o povlačenju tužbe.

Odredbama čl. 94. Novele mijenja se i upozorenje koje je sud dužan dati strankama u pozivu za prvo ročište. Sud će u pozivu za pripremno ročište, među ostalim, upozoriti stranke da će se smatrati da je tužitelj povukao tužbu ako ne dođe na pripremno ročište, da na pripremnom ročištu ne mogu iznositi nove činjenice i predlagati nove dokaze, osim ako ih bez svoje krivnje nisu mogle iznijeti, odnosno predložiti u tužbi, odgovoru na tužbu ili u podnescima u povodu rješenja kojim je ukinut platni nalog (iz čl. 461.a st. 6. ZPP-a), da će na pripremnom ročištu zaključiti prethodni postupak i na istom ročištu održati glavnu raspravu, osim ako zbog navedenih okolnosti slučaja iz čl. 461.a st. 6. ZPP-a to ne bude moguće, te da se odluka može pobijati samo zbog pogrešne primjene materijalnog prava i zbog bitnih povreda odredaba parničnog postupka iz čl. 354. st. 2. ZPP-a, osim zbog povrede iz čl. 354. st. 2. t. 3. ZPP-a, odnosno ako je sud u povodu prigovora stranaka pogrešno odlučio da je stvarno ili mjesno nadležan. Člankom 117. st. 2. Novele propisana je primjena odredaba čl. 94. Novele, a time i odredaba noveliranoga čl. 465. ZPP-a, na sve postupke u tijeku.

Odredbom čl. 95. Novele brisan je čl. 466. ZPP-a. Njome se ukida i posebno pravilo o objavi presude u sporovima male vrijednosti odmah nakon zaključenja glavne rasprave. Člankom 117. st. 2. Novele propisana je primjena odredaba čl. 95. Novele o brisanju čl. 466. ZPP-a na sve postupke u tijeku.

Člankom 96. Novele u cijelosti je izmijenjen dotadašnji čl. 467. ZPP-a., na način da se navedenom odredbom Novele mijenjaju žalbeni razlozi iz kojih se može pobijati odluka kojom se završava spor u postupku u sporovima male vrijednosti. $\mathrm{Na}$ temelju novelirane odredbe čl. 467. st. 1. ZPP-a, presuda ili rješenje kojim se završava spor u postupku u sporovima male vrijednosti može se pobijati samo zbog pogrešne primjene materijalnog prava i zbog bitnih povreda odredaba parničnog postupka iz čl. 354. st. 2. ovoga Zakona, osim zbog povrede iz čl. 354. st. 2. t. 3. ovoga Zakona. Drugim riječima, proširen je krug žalbenih razloga u odnosu na bitne povrede odredaba parničnog postupka. Može se zaključiti da se, de lege lata, presuda ili rješenje kojim se završava spor u postupku u sporovima male vrijednosti može pobijati samo zbog pogrešne primjene materijalnog prava i zbog (apsolutno) bitnih povreda odredaba parničnog postupka (osim zbog razloga iz čl. 354. st. 2. t. 3. ZPP-a). A contrario, presuda ili rješenje kojim se završava spor u postupku u sporovima male vrijednosti ne bi se mogli pobijati žalbom zbog pogrešno ili nepotpuno utvrđenoga činjeničnog stanja (čl. 355. ZPP); zbog relativno bitnih povreda odredaba parničnog postupka (čl. 354. st. 1. ZPP) te zbog toga što je sud u povodu prigovora stranaka pogrešno odlučio da je stvarno ili mjesno nadležan (čl. 354. st. 2. t. 3. ZPP).

Vrlo važna izmjena koju je u parnični postupak unijela Novela odnosi se na to da u sporovima male vrijednosti žalba protiv presude ili rješenja više ne odgađa ovrhu, osim ako sud po službenoj dužnosti, i to iznimno, odredi drukčije. Naime, odredbom čl. 97. Novele u cijelosti je izmijenjen dotadašnji čl. 467.a ZPP-a na način 
da je propisano kako u postupku u sporovima male vrijednosti žalba protiv presude ili rješenja ne odgađa ovrhu, osim ako sud koji donosi presudu ili rješenje, iznimno, po službenoj dužnosti, obrazloženim rješenjem, odredi drukčije. Dakle, u pravilu, žalba nije više suspenzivna. Druga je bitna novina koju je u odredbe dotadašnjega čl. 467.a ZPP-a unijela Novela da nema više revizije po dopuštenju drugostupanjskoga suda, što je u skladu s provedenom važnom i opsežnom reformom instituta revizije u parničnom postupku.

Važna je novina i to da je Novelom propisano kako će se, iznimno, odredbe čl. 94. i 95. Novele primjenjivati (retroaktivno) i na sve postupke u tijeku. ${ }^{81}$

Normativno uređenje postupka u sporovima male vrijednosti gotovo je redovito bilo određeni test za kasniju promjenu uređenja redovnog postupka. Naime, nakon što bi se određena zakonska promjena u sustavu procesno-pravnoga uređenja sporova male vrijednosti pokazala dobrom, bila bi uvelike podloga za zakonske izmjene i uvođenje takvih rješenja u redovni postupak. Vjerujemo da će ta rješenja, nakon njihove primjene u praksi i novih stajališta sudske prakse i procesno-pravne teorije, ukazati na opravdanost njihovoga uvođenja u postupak u sporovima male vrijednosti te da će biti putokaz zakonodavcu da ih umetne i u odredbe ZPP-a kojima se uređuje, tzv. opći parnični postupak, radi provođenja brzog, učinkovitog i racionalnoga parničnog postupka.

\section{LITERATURA}

1. Benzon, Iva i Marija Vujeva. „Postupak u sporovima male vrijednosti - Analiza procesnih instituta u teoriji i praksi nakon Novele Zakona o parničnom postupku iz 2013.“. Pravnik 48, br. 1 (2015.): 23-52.

2. Bulka, Zinka i Dražen Jakovina. Sporovi male vrijednosti. Zagreb: Pravosudna akademija, 2016.

3. Crnić, Ivica. „Promjena u sustavu sporova male vrijednosti“, Informator br. 5764 (2009.): 12-13.

4. Čalija, Branko. Građansko procesno pravo. Sarajevo: Pravni fakultet, 2017.

5. Crnić, Ivica. „Promjena u sustavu sporova male vrijednosti: 2. dio“, Informator br. 5765 (2009.): 8-10.

6. C Čizmić, Jozo. „Postupak u sporovima male vrijednosti “, Hrvatska pravna revija 2, br. 1 (2002.): 113-125.

7. Čuveljak, Jelena. Sporovi male vrijednosti prema noveli Zakona o parničnom postupku 2019., IUS-INFO. Pristup 27.12.2019. http://www.iusinfo.hr/Article/Content.aspx? SOPI $=$ CLN20V01D2019B1315\&Doc $=$ CLANCI_HR

8. Dika, Mihajlo. „Novelirani postupak u sporovima male vrijednosti“, Zbornik Pravnog fakulteta Sveučilišta u Rijeci 30, br. 1 (2009.): 1-32.

9. Hrvatin, Branko. „Nove činjenice i novi dokazi kao razlog za ponavljanje postupka“. U: Aktualnosti hrvatskog zakonodavstva i pravne prakse - Godišnjak 1, Zagreb: Organizator, 1994.: 337-344.

10. Ministarstvo pravosuđa Republike Hrvatske, Prijedlog Zakona o izmjenama i dopunama Zakona o parničnom postupku: Obrazloženje. Zagreb: Ministarstvo pravosuđa, 2019.

81 Željko Pajalić, Novela Zakona o parničnom postupku, Informator, (2019). Novela Zakona o parničnom postupku.ppt. 
11. Pajalić, Željko. Novela Zakona o parničnom postupku, Informator (2019.). Novela Zakona o parničnom postupku.ppt

12. Pavlović, Mladen. „Osobitosti postupka u sporovima male vrijednosti, Pravo i porezi 1, br. 1 (2001.): 39-42.

13. Petrović, Dragoljub, Života Janković; Milka Janković i Hranislav Karamarković. Komentar Zakona o parničnom postupku. Beograd: Privredna štampa, 1977.

14. Poznić. Borivoje. Građansko procesno pravo. Beograd: Privredna štampa, 1995.

15. Preporuke za efikasnije vođenje sporova male vrijednosti. Zagreb: Američka gospodarska komora u Hrvatskoj, 2017.

16. Salma, Marija. „Postupak u sporovima male vrednosti“. Zbornik radova Pravnog fakulteta u Novom Sadu br. 2 (2010.): 121-141.

17. Triva, Siniša, Velimir Belajec i Mihajlo Dika. Građansko parnično procesno pravo. Zagreb: Narodne novine, 1986. 


\title{
Jozo Čizmić*
}

\author{
Summary
}

\section{PROCEEDINGS IN SMALL CLAIMS DISPUTES IN THE LIGHT OF THE PROVISIONS OF NOVEL CPA 2019}

On September 1, 2019, the provisions of the Law on Amendments to the Civil Procedure Act (Official Gazette, No. 70/2019), which, among other things, introduced significant changes in the small claims procedure, became applicable. The purpose of reforming the provisions governing small claims litigation is to enable faster, more efficient and simpler solving of cases that burden the courts with a number that is not such as to require significant involvement of the parties and the court. Thus, for the cause of greater procedural discipline of the parties, the legislature reformed the provisions on the duty to present facts and present evidence; the (presumed) withdrawal of the claim; the grounds for appeal and the suspensive effect of the appeal, and abolished the obligation to publish the judgment immediately after the closing of the main hearing and the possibility to file an (so called) extraordinary revision in these disputes.

As the normative regulation of the small claims procedure was almost regularly a specific test for the subsequent change in the regulation of the ordinary proceedings, we believe that these legal solutions, after their implementation in practice and the standpoints of case law and procedural law theory, will indicate the justification of their introduction in small claims disputes and will be a signpost to the legislator to implement them in the provisions of the Law on civil procedure, which regulates the so-called general litigation, all for the purpose of conducting prompt, efficient and rational litigation.

Keywords: civil procedure; small claims litigation.

Zusammenfassung

\section{VERFAHREN BEI BAGATELLSTREITIGKEITEN IM LICHTE DER BESTIMMUNGEN DER NOVELLE DER ZIVILPROZESSORDNUNG 2019}

Am 1. September 2019 sind die Bestimmungen des Gesetzes über Änderungen und Ergänzungen der Zivilprozessordnung (Amtsblatt der Republik Kroatien Nr. 70/2019), mit welchen man das Verfahren bei Bagatellstreitigkeiten wesentlich

* Jozo Čizmić, Ph.D., Full Professor, Faculty of Law, University of Split; jcizmic@pravst.hr. 
geändert hat, in Kraft getreten. Der Zweck dieser Reform des Verfahrens bei Bagatellstreitigkeiten war, das Beilegen von Streitigkeiten, die durch ihre Zahl die Gerichte überfordern, aber deren Wert kein großes Engagement der Parteien und des Gerichts fordert, schneller, effektiver und einfacher zu machen. Deshalb hat der Gesetzgeber wegen größerer Disziplin der Parteien im Prozess die Bestimmungen über die Plicht der Darstellung von Tatsachen und des Vorschlagens von Beweisen, die (präsumierte) Klagerücknahme, die Berufungsgründe und die aufschiebende Wirkung der Berufung reformiert. Ebenfalls hat er die Pflicht der Urteilsverkündung gleich nach dem Schließen der Hauptverhandlung und die Möglichkeit der außerordentlichen Revision in diesen Streitigkeiten aufgehoben.

Da die normative Regelung von Bagatellstreitigkeiten fast immer ein Test für nachträgliche Änderung des ordentlichen Verfahrens war, ist der Autor der Meinung, dass die Anwendung dieser Bestimmungen in Praxis sowie auch die Stellungen der Rechtsprechung und prozessrechtlichen Theorie auf eine rechtfertigbare Einführung dieser Bestimmungen in das Verfahren bei Bagatellstreitigkeiten hinweisen. Ebenfalls ist das ein Wegweiser für den Gesetzgeber, diese Bestimmungen auch in dem Teil der Zivilprozessordnung, in welchem man den sog. allgemeinen Zivilprozess regelt, zu implementieren, alles mit dem Ziel, den Zivilprozess schneller, effektiver und rationaler zu machen.

Schlüsselwörter: Zivilprozess; Bagatellstreitigkeit.

Riassunto

\section{PROCESSO DELLE CONTROVERSIE DI MODICO VALORE ALLA LUCE DELLE DISPOSIZIONI INTRODOTTE DALLA NOVELLA DELLO LPC 2019}

Le disposizioni della novella della Legge sul processo civile (Gazzetta Ufficiale n. 70/2019) sono entrate in vigore al $1^{\circ}$ settembre 2019 e con esse sono state introdotte modifiche importanti nel processo delle controversie di modico valore. Lo scopo della riforma delle disposizioni con le quali si regola il processo delle controversie di modico valore è di consentire la soluzione dei casi in modo più veloce, efficace $\mathrm{e}$ semplice, posto che tali controversie opprimono a causa del loro elevato numero le corti, non richiedendo un tanto grande impegno né alle parti, né alla corte. A tale fine il legislatore per imporre una maggiore disciplina processuale alle parti, ha riformato le disposizioni sull'obbligo della presentazione dei fatti e della produzione delle prove; sulla (presunzione) del ritiro della domanda; sulle ragioni per l'azione e sull'effetto sospensivo della domanda, eliminando l'obbligo della pubblicazione della sentenza subito dopo la conclusione della fase del dibattimento e la possibilità di richiedere una revisione straordinaria. 
Siccome la regolazione normativa del processo nelle controversie di modico valore è stata quasi sempre un banco di prova per la successiva modificazione del procedimento ordinario, l'autore crede che queste soluzioni, dopo la loro applicazione nella prassi, come anche le opinioni della giurisprudenza e della dottrina processualista, dimostreranno la fondatezza della loro introduzione nel processo delle controversie di modico valore e che esse saranno un orientamento per il legislatore per la loro introduzione anche nelle disposizioni dello LPC nelle quali si regola il cosiddetto processo civile generale ai fini di condurlo velocemente, efficacemente e razionalmente.

Parole chiave: processo civile; controversia di modico valore. 
